\title{
A further record of the spider Microctenonyx subitaneus (Araneae: Linyphiidae: Erigoninae) in Australia
}

\author{
Karl E.C. Brennan \\ Department of Environmental Biology, Curtin University of Technology, GPO Box U1987, \\ Perth, Western Australia, 6845, Australia
}

Linyphiids are tiny to medium spiders ( 1 to $8 \mathrm{~mm}$ in body length) that construct sheet webs. Members of the subfamily Erigoninae are smallest ( 1 to 4 $\mathrm{mm}$ ). They construct tiny sheet webs under stones, in moss or depressions in the soil (Main 1976; Raven et al. 2002a). Despite comprising a large proportion the European fauna, linyphiids represent only a small proportion of described Australian taxa. The Australian fauna comprises 20 genera and 35 described species (Raven et al. 2002b). Five introduced species have been recorded; Diplocephalus cristatus (Blackwall), Eperigone fradeorum (Berland), Erigone prominens Bösenberg and Strand, Microctenonyx subitaneus (O.P. Cambridge), and Ostearius melanopygius (O.P. Cambridge) (Austin et al. 1991; Hirst and Nicolson 1995; Raven et al. 2002c).

Here Microctenonyx subitaneus, from the Erigoninae, is recorded as an additional genus and species present in Western Australia. This finding supports the previous South Australian record by Hirst and Nicolson (1995). Although M. subitaneus is endemic to the holartic (Platnick 2003), it is known from other regions including Africa and New Zealand (Millidge 1988; Scharff 1990). This widespread occurrence has led to many synonyms being created; seven junior synonyms are known (see Platnick 2003).

Specimen identification was by a match of the male palps to Figures 308 and 310 in Millidge (1988). A dorsal view of the carapace, with prominent sulci (pits) behind the posterior lateral eyes, also matched his Figure 309. Lateral view of the carapace, however, revealed a difference to his Figure 301. Rather than all eyes being located on the anterior surface of the carapace, the posterior median eyes were on the dorsal surface. It is unknown whether this represents an abnormal specimen, some plasticity in eye location, or mechanical damage to the specimen during collection.

Further collecting and/or searches of museum collections might reveal other Australian specimens of $M$. subitaneus. It is likely the specimen detailed here was from an established population rather than an immigrant intercepted at its point of entry.
The latter are found usually in urban areas, particularly shipping ports or areas where goods imported from abroad have been stored (e.g., Harvey 1996). This specimen was collected from a rehabilitated mine pit, surrounded by unmined jarrah (Eucalyptus marginata) forest, $45 \mathrm{~km}$ southeast of Perth. That said, the species appears difficult to collect at this locality. Of more than 25,000 spiders identified from Jarrahdale Mine, Western Australia, it is the only known specimen.

It is likely that other described linyphiids will be found in Australia. Raven et al. (2002c) suggest Tenuiphantes cristatus (Menge), may be present although not yet recorded.

\section{MATERIAL EXAMINED}

Australia: Western Australia: 1 male, Jarrahdale Mine $32^{\circ} 16^{\prime} \mathrm{S} 116^{\circ} 06^{\prime} \mathrm{E}$, vacuum sampled from foliage, 8 year-old rehabilitated mine pit surrounded by jarrah forest, October 1997, K.E.C. Brennan (Western Australian Museum specimen number T54593).

\section{ACKNOWLEDGEMENTS}

Thanks to Mark Harvey and Julianne Waldock for confirming the identification plus Mark Harvey, Jonathan Majer and Melinda Moir for constructive criticism of the manuscript.

\section{REFERENCES}

Austin, A.D., De Barro, P. and Harvey, M.S. (1991). The first record of Eperigone fradeorum (Berland) (Linyphiidae) from Australia. Australasian Arachnology 43: 5.

Harvey, M.S. (1996). The first record of the Fiddle-back Spider Loxosceles rufescens (Araneae: Sicariidae) from Western Australia. Records of the Western Australian Museum 18: 223-224.

Hirst, D.B., and Nicolson, L.N. (1995). On new records of Linyphiidae from Australia. Australasian Arachnology 49: 3.

Main, B.Y. (1976). Spiders. Collins, Sydney.

Millidge, A.F. (1988). The spiders of New Zealand: Part 
VI. Family Linyphiidae. Otago Museum Bulletin 6: 3567.

Platnick, N.I. (2003). The World Spider Catalog, Version 4.0. http://research.amnh.org/entomology/spiders / catalog81-87/index.html

Raven, R.J., Baehr, B.C. and Harvey, M.S. (2002a). Spiders of Australia: Interactive Identification to Subfamily. CSIRO Publishing, Melbourne.

Raven, R.J., Lawless, P., Hoath, K., Harvey, M.S. and Hirst, D.B. (2002b). Checklist of Australian spiders. In: Raven, R.J., Baehr, B.C. and Harvey, M.S. Spiders of
Australia: Interactive Identification to Subfamily. CSIRO Publishing, Melbourne.

Raven, R.J., Harvey, M.S. and Hirst, D.B. (2002c). Introduced spiders of Australia. In: Raven, R.J., Baehr, B.C. and Harvey, M.S. Spiders of Australia: Interactive Identification to Subfamily. CSIRO Publishing, Melbourne.

Scharff, N. (1990). A catalogue of African Linyphiidae (Araneae). Steenstrupia 16: 117-152.

Manuscript received 19 September 2003; accepted 11 December 2003 


\section{Guide to Authors}

\section{Subject Matter:}

Reviews, observations and results of research into all branches of natural science and human studies will be considered for publication. However, emphasis is placed on studies pertaining to Western Australia. Longer papers will be considered for publication as a Supplement to the Records of the Western Australian Museum. Short communications should not normally exceed three typed pages and this category of paper is intended to accommodate observations, results or new records of significance. that otherwise might not get into the literature, or for which there is a particular urgency for publication. All material must be original and not have been published elsewhere.

\section{Presentation:}

Authors are advised to follow the layout and style in the most recent issue of the Records of the Western Australian Museum including headings, tables, illustrations and references.

The title should be concise, informative and contain key words necessary for retrieval by modern searching techniques. An abridged title (not exceeding 50 letter spaces) should be included for use as a running head.

An abstract must be given in full length papers but not short communications, summarizing the scope of the work and principal findings. It should normally not exceed $2 \%$ of the paper and should be suitable for reprinting in reference periodicals.

The International System of units should be used.

Numbers should be spelled out from one to nine in descriptive text; figures used for 10 or more. For associated groups, figures should be used consistently, e.g. 5 to 10 , not five to 10 .

Spelling should follow the Concise Oxford Dictionary.

Systematic papers must conform with the International Codes of Botanical and Zoological Nomenclature and, as far as possible, with their recommendations.

Synonymies should be given in the short form (taxon, author, date, page) and the full reference cited at the end of the paper. All citations, including those associated with scientific names, must be included in the references.

\section{Manuscripts:}

The original and two copies of manuscripts and figures should be submitted to the Editors, c/ Publications Department. Western Australian Museum, Francis Street, Perth. Western Australia 6000. They must be in double-spaced typescript on A4 sheets. All margins should be at least $30 \mathrm{~mm}$ wide. Tables plus heading and legends to illustrations should be typed on separate pages. The desired position for insertion of tables and illustrations in the text should be indicated in pencil. Tables should be numbered consecutively, have headings which make them understandable without reference to the text, and be referred to in the text.

High quality illustrations are required to size $(16.8 \mathrm{~cm} \times 25.2 \mathrm{~cm})$ or no larger than $32 \mathrm{~cm} \times 40$ $\mathrm{cm}$ with sans serif lettering suitable for reduction to size. Photographs must be good quality black and white prints, not exceeding $16.8 \mathrm{~cm} \times 25.2 \mathrm{~cm}$. Scale must be indicated on illustrations. All maps, line drawings, photographs and graphs, should be numbered in sequence and referred to as Figure/s in the text and captions. Each must have a brief, fully explanatory caption. On acceptance a computer disk containing all corrections should be sent with amended manuscript. The disk should be marked with program (e.g. Word, WordPerfect, etc).

In papers dealing with historical subjects references may be cited as footnotes. In all other papers references must be cited in the text by author and date and all must be listed alphabetically at the end of the paper. The names of journals are to be given in full.

\section{Processing:}

Papers and short communications are reviewed by at least two referees and acceptance or rejection is then decided by the editors.

The senior author is sent one set of page proofs which must be returned promptly.

The senior author will receive fifty free offprints of the paper. Additional offprints can be ordered at page proof stage. 


\section{Records of the Western Australian Museum Volume 22 Part 22004}

\section{CONTENTS}

\section{C.S. Whisson, F.E. Wells and T. Rose}

The benthic invertebrate fauna of the Peel-Harvey Estuary of south-western Australia after completion of the Dawesville Channel

M.A. Cowan and R.A. How

Comparisons of ground vertebrate assemblages in arid Western Australia

in different seasons and decades

\section{P.A. McLaughlin}

A new genus and species of hermit crab (Crustacea: Anomura:

Paguroidea) from northwestern Australia

\section{W. Zeidler and L. Gershwin}

A new species of Australomedusa (Cnidaria: Hydrozoa: Anthomedusae)

from a saline lake in south-western Western Australia

J.T. Jennings, A.D. Austin and N.B. Stevens

The aulacid wasp fauna of Western Australia with descriptions of six new species

\section{E.M. Exley}

Revision of the genus Dasyhesma Michener (Apoidea: Colletidae: Euryglossinae)

D.L. Morgan, M.G. Allen, P. Bedford and M. Horstman

Fish fauna of the Fitzroy River in the Kimberley region of Western Australia - including the Bunuba, Gooniyandi, Ngarinyin, Nyikina and

Walmajarri Aboriginal names

\section{SHORT COMMUNICATION}

\section{K.E.C. Brennan}

A further record of the spider Microctenonyx subitaneus

(Araneae: Linyphiidae: Erigoninae) in Australia 